\title{
Occurrence of Chandleronema longigutturata (Nematoda: Acuariidae) in Procyon cancrivorus in the Neotropical region
}

\author{
Ocorrência de Chandleronema longigutturata (Nematoda: Acuariidae) em \\ Procyon cancrivorus na região neotropical
}

\author{
Alice Graciela Rodriguez Suárez ${ }^{1 *}$; Tatiana Cheuiche Pesenti ${ }^{1}$; Márcia Raquel Pegoraro de Macedo ${ }^{1}$; \\ Carolina Silveira Mascarenhas ${ }^{1}$; Gertrud Müller Antunes ${ }^{1}$
}

\begin{abstract}
${ }^{1}$ Laboratório de Parasitologia de Animais Silvestres, Departamento de Biologia e Parasitologia, Instituto de Biologia, Universidade Federal de Pelotas - UFPel, Pelotas, RS, Brasil
\end{abstract}

Received September 18, 2014

Accepted October 27, 2014

\begin{abstract}
Procyon cancrivorus is a wild animal that is found from Central America to Uruguay and northeastern Argentina. It is one of the least studied carnivore species in Brazil. For the purpose of identifying helminths that parasitize P. cancrivorus, individuals of this species that had been run over and killed by motor vehicles were collected from highways in the southern part of the state of Rio Grande do Sul. At necropsy, their organs, along with organ contents and mucous membranes, were examined for parasite collection. The nematodes found in the stomachs of these Procyonidae were cleared with lactophenol and Chandleronema longigutturata was identified. This report provides the first record of occurrences of C. longigutturata in the Neotropical region and its parasitism in P. cancrivorus.
\end{abstract}

Keywords: Procyon cancrivorus, Chandleronema longigutturata, Nematoda, neotropical.

\section{Resumo}

Procyon cancrivorus é um animal silvestre que se distribui desde a América Central até o Uruguai e Nordeste da Argentina. Está entre as espécies de carnívoros brasileiros menos estudadas. Com o objetivo de identificar helmintos que parasitam $P$. cancrivorus, estes foram coletados nas estradas, quando mortos por atropelamento automobilístico, na região Sul do Rio Grande do Sul. Após a necropsia, os órgãos foram examinados, assim como suas mucosas e conteúdos para a coleta de parasitos. Os nematoides encontrados no estômago desses procionídeos foram clarificados com lactofenol e identificados à Chandleronema longigutturata. Registra-se pela primeira vez a ocorrência de C. longigutturata na região neotropical, bem como o parasitismo em $P$. cancrivorus.

Palavras-chave: Procyon cancrivorus, Chandleronema longigutturata, Nematoda, neotropical.

Procyon cancrivorus, also known as the raccoon or crab-eating raccoon, belongs to the Procyonidae family and is found from Central America to Uruguay and northeastern Argentina. It occurs in all Brazilian biomes (REIS et al., 2006), and is one of the least studied carnivore species in this country (MORATO et al., 2004). In Brazil, it is popularly called "mão pelada" (bare paws) due to its furless paws (CAMERA \& MURTA, 2003, apud PEREIRA et al., 2010).

Wild animals are reservoirs for various parasites. Studies on overall parasite fauna and biodiversity are based mainly on the importance of parasites as disease agents affecting ecosystems and the health of natural and domestic environments (BROOKS \& HOBERG, 2001).

Environmental problems affect the ecological balance and end up bringing wild animals closer to humans and pets. This

${ }^{*}$ Corresponding author: Alice Graciela Rodriguez Suárez, Universidade Federal de Pelotas - UFPel, CP 354, CEP 96010-900, Pelotas, RS, Brasil, e-mail: mendes_graciela@hotmail.com closer contact allows dissemination of infectious and parasitic agents into new hosts and environments, thereby establishing new relationships that affect the disease transmission chain. As a result of these negative interactions, zoonoses of large epidemic extent and greater geographical spread of these agents may occur (BARTLETT \& JUDGE, 1997).

Analyses on parasite diversity among wild animals can be a good indicator of ecosystem health, since this diversity reflects the phylogeny and conditions that enable symbiosis between parasites and hosts and therefore shows the evolutionary pressure on both of them (CHAI et al., 2005).

Nine of $P$. cancrivorus specimens were collected from highways in the southern part of the state of Rio Grande do Sul, where they had been run over and killed by motor vehicles (Authorization No. 38913-1 SISBIO/RS; EAEC/UFPel-07/05/2009). The animals collected were placed in individual plastic bags and were transported in coolers to the Laboratory of Wild-Animal Parasitology of the Federal University of Pelotas, where they were necropsied. 
Their organs were then removed, opened and washed in a 106-micrometer mesh sieve. Each organ was examined under a stereomicroscope, and its contents were washed in order to collect any helminths that were present. The nematodes found were fixed in ethanol $\left(70{ }^{\circ} \mathrm{GL}\right)$, clarified with Aman's lactophenol for identification in accordance with Little \& Ali (1980) and then photographed under an Olympus BX41 microscope with an adapted camera system.

Out of the nine $P$. cancrivorus examined, six were parasitized by Chandleronema longigutturata, which was found in their stomachs. Among these parasites, 33 were females and four were males, and larval forms were also observed. Their measurements are shown in Table 1.

The genera of the subfamily Acuariidae are differentiated mainly in relation to their cuticular base and structures such as cordons, thorns, papillae, etc. (CHABAUD, 1975). Nematodes of the Acuariidae family mainly parasitize birds, but species other than $C$. longigutturata have been reported in mammals, such as Paracuaria soricis (JANÇEV, 1972) and Stammerinema soricis (TINER, 1951) in soricines; Synhimanthus australiensis (BEVERIDGE \& BARKER, 1975) and Antechiniella suffodiax
(BEVERIDGE \& BARKER, 1975) in rodents and marsupials; and Skrjabinoclava thapari (TEIXEIRA DE FREITAS, 1953 apud VICENTE et al., 1997) in P. cancrivorus in Brazil.

Chandler (1942) apud Chandler (1980) reported that nematodes found in the stomachs of raccoons presented morphological characteristics similar to those of the genus Synhimanthus. However, Little \& Ali (1980) redescribed the parasites, classifying them as belonging to the genus Chandleronema because of their cephalic cords characteristics and their cylindrical and exceptionally long pharynx.

The characteristics of these nematodes found in the stomach of P. cancrivorus included short, delicate, recurrent and anastomosing cephalic cordons (Figures 1b and 1c.); a small cephalic dilation and a long pharynx (Figure 1b); tricuspid papillae (Figures 1a and 1d); spicule morphology (Figure 1e); four pairs of pre-cloacal papillae and five pairs in the post-cloacal region; and eggs conforming with the description of C. longigutturata by Little \& Ali (1980).

Birds and the procyonid P. cancrivorus have similar diets (fish, crustaceans, snails, seeds, etc.) thus enabling both of them, albeit differently, to host the same parasites.
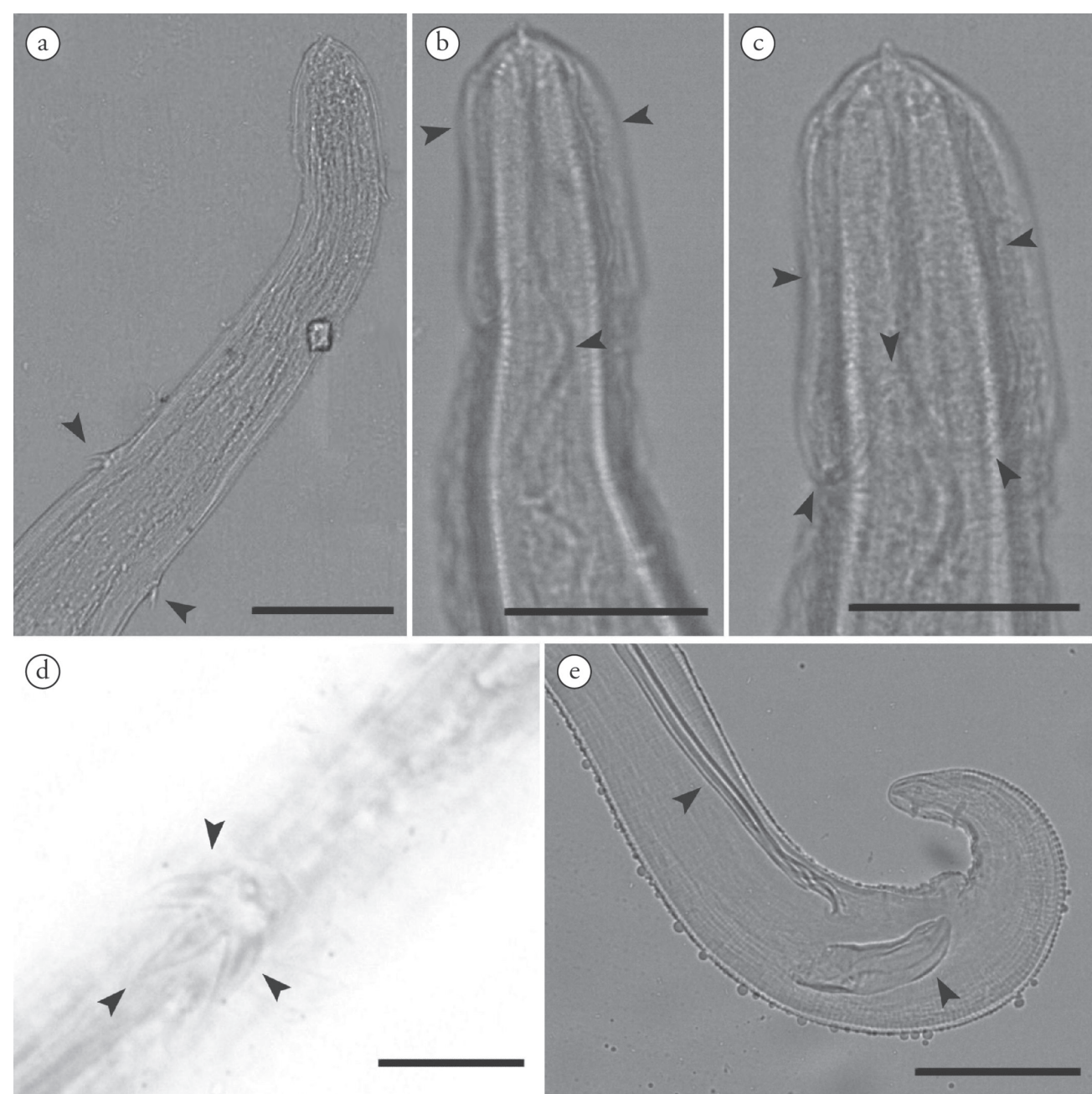

Figure 1. Chandleronema longigutturata (Nematoda: Acuariidae) parasitizing Procyon cancrivorus in southern Brazil. At the anterior extremity, the arrow head shows the cervical papillae (a), cephalic dilation and pharynx (b) and recurrent and anastomosing cordons (c); bar $=0.11 \mu \mathrm{m}$. Lateral view of cervical papilla (d); bar $=0.3 \mu \mathrm{m}$. Lateral view of posterior extremity of male (e), with arrow head showing spicule; bar $=0.1 \mu \mathrm{m}$. 
Table 1. Sizes of Chandleronema longigutturata specimens (in $\mu \mathrm{m}$ ), parasitizing Procyon cancrivorus in the Neotropical region.

\begin{tabular}{lll}
\hline \multicolumn{1}{c}{ Estruturas } & $\begin{array}{c}\text { Female } \\
(\mathbf{n}=\mathbf{3})\end{array}$ & $\begin{array}{l}\text { Male } \\
(\mathbf{n}=\mathbf{1})\end{array}$ \\
\hline Total length & 4.73 & 4.62 \\
Width & 0.112 & 0.92 \\
Pharynx & 0.132 & 0.130 \\
Anterior esophagus & 0.262 & 0.212 \\
Nerve ring & 0.237 & 0.217 \\
Cordons & & \\
Base & 0.082 & 0.087 \\
Recurrent & 0.075 & 0.082 \\
Cervical papillae & 0.3 & 0.3 \\
Vulva & 1.62 & - \\
Spicule & & \\
Long & -- & 0.462 \\
Short & -- & 0.105 \\
\hline
\end{tabular}

$\mathrm{n}=$ number of species; $\mathrm{X}=$ average.

\section{References}

Bartlett PC, Judge LJ. The role of epidemiology in public health. Rev Sci Tech 1997; 16(2): 331-336. PMid:9501345.

Beveridge I, Barker IK. Acuariid, capillariid and hymenolepidid parasites of the dasyurid marsupial Antechinus stuartii Macleay, 1841, from southeastern Australia. J Helminthol 1975; 49(4): 211-227. http://dx.doi. org/10.1017/S0022149X00026225. PMid:1206212

Brooks DR, Hoberg EP. Parasite systematics in the 21st century: opportunities and obstacles. Trends Parasitol 2001; 17(6): 273-275. http://dx.doi.org/10.1016/S1471-4922(01)01894-3. PMid:11378033
Chabaud AG. Keys to the genera of the order Spirurida. Spiruroidea, Habronematoidea and Acuarioidea. In: Anderson RC, Chabaud AG, Willmott S. Keys to the nematode parasites of vertebrates 3. Part 2. England: Commonwealth Agricultural Bureaux; 1975. p. 29-58.

Chai JY, Darwin Murrell K, Lymbery AJ. Fish-borne parasitic zoonoses: status and issues. Int J Parasitol 2005; 35(11-12): 1233-1254. http:// dx.doi.org/10.1016/j.ijpara.2005.07.013. PMid:16143336

Chandler AC. The helminths of raccoons in east Texas. J Parasitol 1980; 28(4): 255. http://dx.doi.org/10.2307/3272963.

Jançev JI. Paracuaria soricis n. sp. (Acuariidae) of Sorex araneus L. in Bulgaria. Comp Rend Acad Bulgar Scienc 1972; 25(5): 693-695.

Little MD, Ali MM. Chandleronema longigutturata (Chandler 1942) gen. et comb. n. (nematoda: acuariidae) from raccoons, Procyon lotor, in Louisiana. J Parasitol 1980; 66(3): 555-558. http://dx.doi. org/10.2307/3280763. PMid:7391894

Morato RG, Rodrigues FHG, Eizirik E, Manguini PR, Azevedo FCC. Plano de Ação: pesquisa e conservação de mamíferos carnivoros do Brasil. 2. ed. Brasília: IBAMA; 2004. p. 52.

Pereira FC, Lima VM, Pereira KF. Morfologia dos músculos da coxa de mão-pelada (Procyon cancrivorus) - Cuvier, 1798. Ciênc Anim Bras 2010; 11(4): 947-954.

Reis NR, Peracchi AL, Pedro WA, Lima IP. Mamiferos do Brasil. Londrina: Editora Universidade Estadual de Londrina; 2006.

Tiner JC. Dispharynx soricis n. sp. (Nematoda: Acuariidae) from the Shrew Sorex obscurus alascensis and associated host pathology. Proc Helminthol Soc Wash 1951; 18: 64-70.

Vicente JJ, Rodrigues HO, Gomes DC, Pinto RM. Nematóides do Brasil. Parte V: Nematóides de mamíferos. Rev Bras Zool 1997; 14(S1): 1-452. 